\title{
Research Progress on Catalytic Pyrolysis and Reuse of Waste Plastics and Petroleum Sludge
}

Duo Pan, ${ }^{1}$ Fengmei Su, ${ }^{1, *}$ Hu Liu, ${ }^{1}$ Chuntai Liu, ${ }^{1}$ Ahmad Umar, ${ }^{2,3, *}$ L. Castañeda, ${ }^{4}$ Hassan Algadi, ${ }^{3,5}$ Caiyun Wang ${ }^{6, *}$ and Zhanhu $\mathrm{Guo}^{7, *}$

\begin{abstract}
Waste plastics (e.g., polyethylene, polyvinyl chloride, polypropylene, polystyrene) and petroleum sludge (i.e., main residual from the petroleum industry) pose a severe threat to the environment and human health. These materials are basically nonbiodegradable, and it is difficult to realize the recycling of them and resources via traditional treatment methods. Catalytic pyrolysis as a new recycling treatment method has the characteristics of high efficiency, environmentally benign, no secondary pollution and high product utilization value. This paper mainly reviews the research progress of catalysts used in the catalytic pyrolysis of waste plastics and petroleum sludge. They include molecular sieves, transition metals, metal oxides, clays and activated carbons used for the recycling of plastic, and molecular sieves and $\mathrm{M}$-series catalyst ( $\mathrm{M}=\mathrm{Al}, \mathrm{Fe}, \mathrm{Ca}, \mathrm{Na}, \mathrm{K}$ ) for treating petroleum sludge. The mechanism of catalytic pyrolysis is also elucidated in this paper. In addition, the challenges faced by catalytic pyrolysis of waste polymers and the future development prospects are also presented.
\end{abstract}

Keywords: waste plastics; petroleum sludge; catalytic pyrolysis; catalysts; recycling.

Received date: 11/18/2020; Accepted date: 30 January 2021.

Article type: Review article.

\section{Introduction}

The discovery and exploitation of petroleum have greatly promoted the progress of human civilization. Fuel, plastics, rubber, paint and medicine that are produced from the processed petroleum are widely used in various fields of human life. ${ }^{[1]}$ Among them, as one of the great inventions of modern society, plastic products greatly enrich the daily life of human beings. ${ }^{[2]}$ The exploitation and deep processing of petroleum (such as synthetic plastics) is accompanied with the production of petroleum sludge. Both petroleum sludge and waste plastics have potential recycling value. ${ }^{[3]}$

The mass production and use of plastic products has brought many problems while promoting the economic

\footnotetext{
${ }^{I}$ Key Laboratory of Materials Processing and Mold (Zhengzhou University), Ministry of Education; National Engineering Research Center for Advanced Polymer Processing Technology, Zhengzhou University, Zhengzhou, 450002, China.

${ }^{2}$ Department of Chemistry, Faculty of Science and Arts, Najran University, Najran-11001, Kingdom of Saudi Arabia.

${ }^{3}$ Promising Centre for Sensors and Electronic Devices (PCSED), Najran University, Najran-11001, Kingdom of Saudi Arabia.

${ }^{4}$ Sección de Estudios de Posgrado e Investigación de la Escuela Superios de Medicina, Instituto Politécnico Nacional, Plan of San Luis and Díaz Mirón S/N, Casco de Santo Tomás, Alcaldía Miguel Hidalgo, C. P. 11340, Cd. de México, México.
}

growth and improving living standards of the people. The plastics used in the industry and daily life are mostly synthetic polymer materials such as polypropylene (PP), polyethylene (PE), polystyrene (PS) and polyvinyl chloride (PVC) ${ }^{[4]}$ Huge quantities of plastics have been discarded after the use. Waste plastics cannot be easily decomposed in the natural environment. They cause serious pollution to the atmosphere, soil and water environment, as well as the waste in the form of resources and energy. ${ }^{[5,6]}$ In particular, disposable plastic bags and agricultural plastic films used in our daily life are discarded and cause visual pollution, that is "white pollution". On one hand, these "white pollution" seriously affects the growth of crops, the reproduction of fish and even make some rare marine species endangered. On the other hand, the diet containing food with plastic residue will cause serious health

${ }^{5}$ Department of Electrical Engineering, Faculty of Engineering, Najran University, Najran-11001, Kingdom of Saudi Arabia.

${ }^{6}$ ARC Centre of Excellence for Electromaterials Science, Intelligent Polymer Research Institute, AIIM Facility, University of Wollongong, North Wollongong, NSW 2500, Australia.

${ }^{7}$ Integrated Composites Laboratory (ICL), Department of Chemical \& Biomolecular Engineering, University of Tennessee, Knoxville, TN 37996, USA.

*E-mail: fmsu@zzu.edu.cn (F. Su),zguo10@utk.edu (Z. Guo), caiyun@uow.edu.au (C.Wang), ahmadumar786@gmail.com (A. Umar). 
problems. ${ }^{[7]}$ In June 2018, National Geographic magazine used a photo titled "Planet or plastic?" as the cover image, it called on the society to pay attention to the plastic crisis and pointed out that one of the biggest environmental problems facing human beings in this era was plastic pollution. ${ }^{\left[{ }^{[8}\right.}$

As the main raw material of polymer products, petroleum is inevitably mixed with soil or other impurities to form petroleum sludge due to accidents, natural precipitation and other reasons in the processes of exploitation, storage and transportation, refining and tank cleaning. ${ }^{[9]}$ When the petroleum sludge enters into the ground, it destroys the physical and chemical properties of soil deteriorating the soil quality and causing damage or death to vegetation. When petroleum sludge enters the river, it destroys the balance of water ecosystem, also cause the concentration of petroleum hydrocarbons in the water increase exceeding the standard and pollute the groundwater. ${ }^{[10]}$ In addition, petroleum sludge contains polycyclic aromatic hydrocarbons that can also release a lot of harmful gases and dust,polluting the environment and threatening human health. ${ }^{[11]}$

As can be seen from Fig. 1, the traditional treatments for waste plastics and petroleum sludge are landfill and incineration. However, landfill requires a large amount of space and sufficient soil to fully seal and prevent the leaching of harmful compounds, which not only seriously waste land resources but also pollute groundwater resources and cause landfills to become soft foundations. ${ }^{[12]}$ Although incineration greatly reduces the volume and mass of waste plastics and petroleum sludge, a large amount of toxic and harmful gases (e.g. nitrogen oxides, $\mathrm{HC} 1, \mathrm{HCN}$, etc.) are generated during the incineration process, which has a negative impact on the environment and causes secondary pollution. ${ }^{[13]}$ To some extent, waste is a misplaced resource, which hides great potential value. Therefore, in addition to these two commonly used direct disposal methods, the third method is recycling treatment. It includes physical/mechanical recycling and chemical recycling. ${ }^{[14]}$ The physical or mechanical recycling method has high standard requirement for waste plastics and petroleum sludge, single type or no impurities. Therefore, it needs a large amount of pre-processing works such as sorting, which greatly limits the scope of application. ${ }^{[15]}$ In contrast, the chemical recycling method has the low requirement for waste materials and can process various types of mixed plastics and petroleum sludge. It is environmentally friendly with low pollution and low emissions. Most importantly, it is widely accepted for the high utilization rate of the processed object and high value-added products. ${ }^{[16]}$

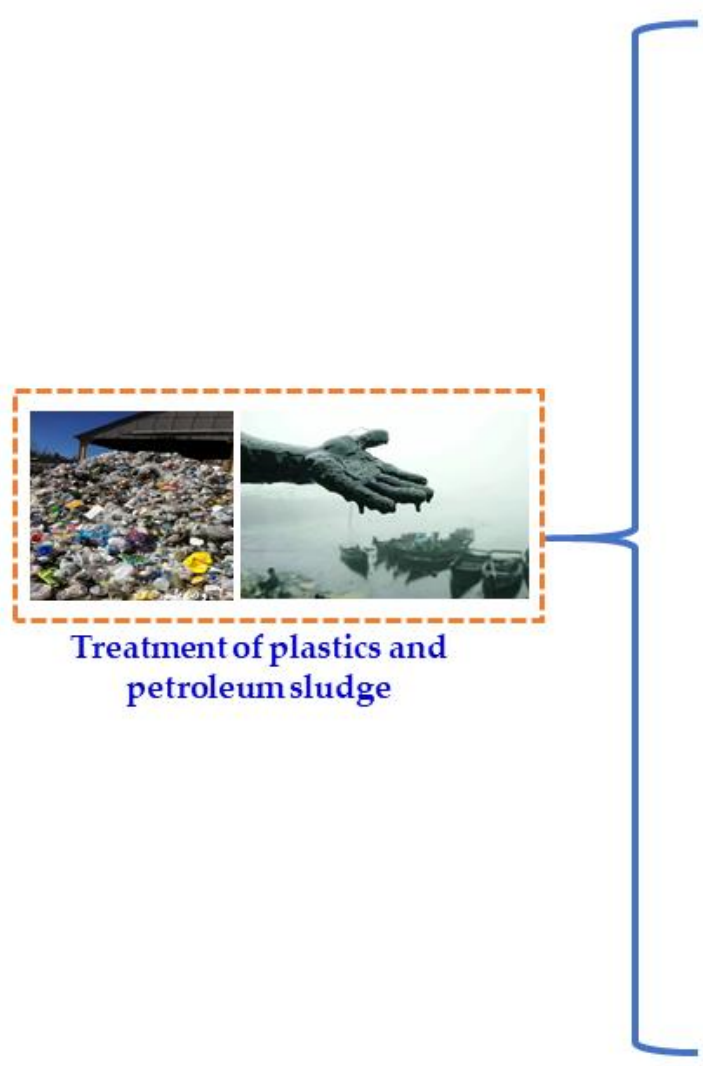

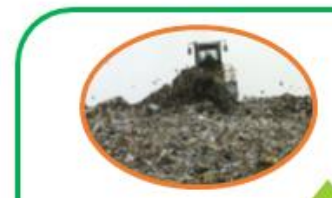

Landfill

Traditional method
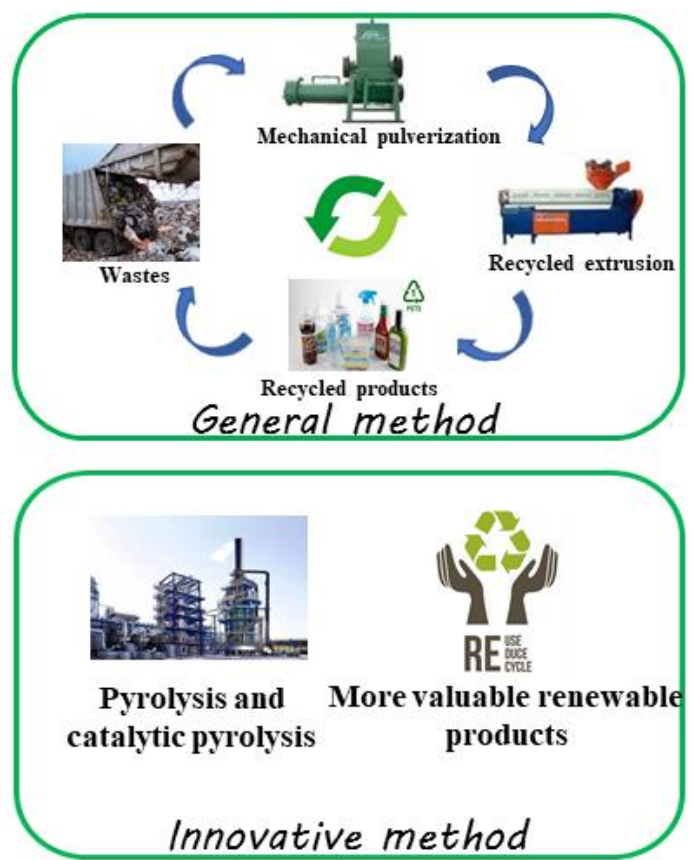

Fig. 1 Various treatment methods for waste plastics and petroleum sludge. 


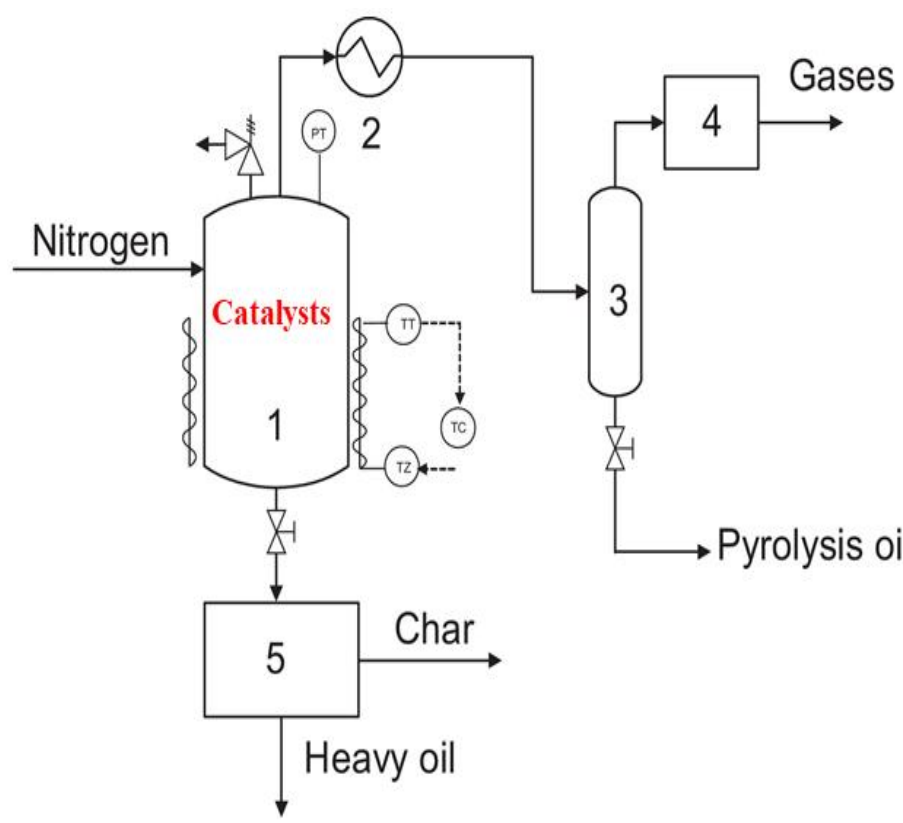

Fig. 2 The Process for catalytic pyrolysis of organic polymers (1: reactor; 2: water cooler; 3: separator; 4: gas meter; 5: filter).

Pyrolysis and catalytic pyrolysis are two relatively mature and efficient chemical recycling methods. Pyrolysis refers to placing raw materials in a pyrolysis reactor and heating them directly in an oxygen-free or anoxic atmosphere. ${ }^{[17]}$ Under high temperature conditions, $\mathrm{C}-\mathrm{C}$ bonds and $\mathrm{C}-\mathrm{H}$ bonds in the polymer are broken to obtain hydrocarbons with different lengths, and then fuel oil is obtained after further fractionation. ${ }^{[18]}$ The catalytic pyrolysis method is to simultaneously add the reaction materials (waste plastics or petroleum sludge) and catalysts into the pyrolysis kettle. The specific process is shown in Fig. 2. In the presence of catalyst, the unstable carbocations are broken and the linear molecules is significantly reduced, while non-linear molecules are greatly increased. ${ }^{[19]}$ Compared with the direct pyrolysis method, the catalytic pyrolysis method offers the advantages of fast reaction rate, short reaction time, low reaction temperature, and higher quality value-added product sat low cost. ${ }^{[20,21]}$

Despite there have been many reports on the pyrolysis and catalytic pyrolysis of waste plastics and petroleum sludge, there is few comprehensive systematic review available. This work briefly summarizes the main chemical composition of cracked waste plastics and petroleum sludge, as well as a detailed overview of the research progress of different catalysts in catalytic pyrolysis of waste plastics and petroleum sludge.

\section{The main compositions and pyrolysis of waste plastics 2.1 Low-density polyethylene (LDPE)}

Low-density polyethylene (LDPE), also called high-pressure polyethylene, is formed by high-pressure polymerization of ethylene and a small amount of olefin. ${ }^{[22]}$ The molecular structure is mainly composed of linear main chain and contains many short-chain branches, which has low crystallinity and is easy to be heated and formed. ${ }^{[23]}$ Therefore, it is widely used as packaging plastic bags, disposable garbage bags, etc. in daily life. LDPE waste is accumulated over time and is recognized as the second largest type of plastics in municipal solid waste. The thermal cracking of LDPE into petroleum products as a method of recycling energy and reducing waste of resources has now received extensive attention.

Yan et al. ${ }^{[17]}$ conducted a pyrolysis study of LDPE in an atmospheric nitrogen semi-batch reactor by a modified CoatsRedfern method. At the temperature of $420-460{ }^{\circ} \mathrm{C}$, the content of gasoline $\left(\mathrm{C}_{6}-\mathrm{C}_{12}\right)$ fraction in cracked product reached $21.30 \mathrm{wt} \%$, and the content of diesel $\left(\mathrm{C}_{13}-\mathrm{C}_{22}\right)$ fraction reached $67.76 \mathrm{wt} \%$.

\subsection{High-density polyethylene (HDPE)}

High-density polyethylene (HDPE), also called low-pressure polyethylene, has a highly regular molecular structure with high crystallinity, melting point and density and few and short branches in its molecules. ${ }^{[24]}$ HDPE is commonly used in the manufacturing of container bottles and toys, based on high strength characteristics. At room temperature, HDPE is insoluble in any organic solvent and has high corrosion resistance to acids, bases and salts. In municipal solid waste, it is the third largest plastic type. ${ }^{[25]}$

Al-Salem et al. ${ }^{[26]}$ have carried out pyrolysis of HDPE in a new fixed bed (intermittent) reactor to produce the gasoline range hydrocarbon oils. The optimum temperature for obtaining the maximum oil yield $(70 \mathrm{wt} \%)$ in the presence of inert carrier gas nitrogen was $550{ }^{\circ} \mathrm{C}$. The research found that the recovered pyrolysis oil products contained a higher proportion of aliphatic hydrocarbons, a lower proportion of aromatic hydrocarbons, and the carbon content of the pyrolysis oil increases with increasing temperature.

\subsection{Polyvinyl chloride (PVC)}

Polyvinyl chloride (PVC) is a unique thermoplastic derived from polyethylene. The addition of chlorine gives PVC excellent fire resistance and electrical insulation. ${ }^{[27]}$ For general-purpose plastics, PVC is largely used. It is widely used in wire and cable insulation materials, building materials, automotive interiors, credit cards, synthetic leathers when mixed with various additives. Although PVC has a wide range of applications, there are few literatures on its pyrolysis due to the release of harmful gases upon heating.

Miskolczi et al. ${ }^{[28]}$ studied the effects of PVC content on the yield and properties of products (gases, gasoline, light and heavy oil) by placing PVC-containing municipal solid waste in a horizontal tubular reactor and treating them at $530{ }^{\circ} \mathrm{C}$ for 25 minutes. The results show that the mixed plastic waste samples with different PVC content can be converted into gasoline and light oil with a yield of 36.9-59.6\%, and the decomposition conversion rate increases significantly with the increase of PVC concentration. 


\subsection{Polypropylene (PP)}

Polypropylene (PP)is polymerized from propylene and has good chemical and heat resistance due to the presence of methyl side chains in the structure. PP is lower in density than HDPE, but higher in hardness and rigidity. PP does not melt at temperatures below $160{ }^{\circ} \mathrm{C}$, which making it popular in the plastics industry and widely used in washbasins, buckets and carpet materials, etc. ${ }^{[29]} \mathrm{It}$ is counted as the largest amount of plastic found in municipal solid waste. The demand for PP has increased year by year.

Ahmad et al. ${ }^{[30]}$ studied PP pyrolysis fuel products at temperatures ranging from $250-400{ }^{\circ} \mathrm{C}$. As a result, it was found that the product yield was highly correlated with the change in temperature and the total conversion at the temperature of $300{ }^{\circ} \mathrm{C}$ was as high as $98.66 \%$ (69.82\% of liquid, $28.84 \%$ of gases and $1.34 \%$ of residue). By Fourier transform infrared spectra (FT-IR) and Gas chromatography coupled with mass spectrophotometry (GC-MS)analysis of liquid product fractions, the findings suggest that the liquid fractions consist of a wide variety of hydrocarbons distributed in $\mathrm{C}_{6}-\mathrm{C}_{16}$.

\subsection{Polystyrene (PS)}

Polystyrene(PS) is a high molecular weight polymer synthesized by free radical polymerization of styrene monomer. It is usually colorless and transparent, and its transmittance can reach more than $90 \%$. It has good electrical insulation performance, good processing fluidity, heat resistance, chemical corrosion resistance, and is easy to color. They have been widely used in the fields of disposable foam lunch boxes, food packaging and household appliances. ${ }^{[31]}$ There is a large amount of PS waste in the accumulated municipal solid waste every year. Unfortunately, PS cannot be properly classified and recycled in urban life. Therefore, in order to avoid waste of resources, it is of great significance to use pyrolysis to convert into more valuable petroleum products.

Onwudili et al. ${ }^{[32]}$ performed a pyrolysis experiment on PS under an inert nitrogen atmosphere in a closed batch reactor to study the effect of reaction temperature on pyrolysis products. From the experiment, they found that the liquid fuel oil yield was as high as $97.0 \mathrm{wt} \%$ when the pyrolysis temperature was $425{ }^{\circ} \mathrm{C}$, and the obtained liquid oil was almost entirely composed of aromatic compounds, especially toluene, ethylbenzene and styrene.

\section{The main compositions and pyrolysis of petroleum sludge}

Petroleum sludge mainly contains the chemical compositions of alkanes, cycloalkanes, aromatic hydrocarbons and so on. The recycling of petroleum sludge is mainly realized by heat treatment of the heavy oil components. Under the action of pyrolysis, hydrocarbons undergo complex chemical reactions mainly including endothermic pyrolysis reaction and exothermic condensation reaction. During the reaction, heavy oil generally begins to decompose at around $370{ }^{\circ} \mathrm{C}$, and the condensation reaction accelerates as increase of pyrolysis temperature. ${ }^{[33]}$

The pyrolysis of alkanes in petroleum sludge mainly includes the formation of small molecular alkenes and secondary alkanes after the $\mathrm{C}-\mathrm{C}$ bond is broken and the formation of alkenes with a constant carbon number after the $\mathrm{C}-\mathrm{H}$ bond is broken. The general formula can be expressed as: ${ }^{[34]}$

$$
\begin{gathered}
\mathrm{R}-\mathrm{CH} 2 \mathrm{CH} 2-\mathrm{R}^{\prime} \rightarrow \mathrm{R}-\mathrm{CH}=\mathrm{CH} 2+\mathrm{R}^{\prime} \mathrm{H} \\
\mathrm{R}-\mathrm{CH} 2 \mathrm{CH} 3 \rightarrow \mathrm{R}-\mathrm{CH}=\mathrm{CH} 2+\mathrm{H} 2
\end{gathered}
$$

The pyrolysis of cycloalkanes is mainly a process of fracturing alkyl ring and alkyl side chain, in which the ring of cycloalkane is broken and form smaller molecular olefins or alkadienes, and the alkyl side chain is broken to form smaller molecule alkanes or olefins. Since aromatic hydrocarbon is relatively stable, the aromatic ring cannot be broken at low temperature. At high temperature, the dehydrogenation condensation reaction is carried out to form another aromatic hydrocarbon with larger number of rings and finally form coke. The complexity of the pyrolysis reaction of petroleum sludge is that some of the obtained intermediate products undergo cracking reaction with heating, but all the reactions follow the free radical reaction mechanism of chain initiation, chain growth and chain termination. ${ }^{[35,36]}$

Shen et $a .^{[37]}$ conducted a pyrolysis experiment of petroleum sludge in a fluidized bed. It was found that when the temperature was $525{ }^{\circ} \mathrm{Cand}$ the gas phase residence time was $1.5 \mathrm{~s}$, the maximum oil production was $30 \%$ of the total sludge weight. Moreover, the oil yield gradually decreases as the residence time of gas phase increases. The reason is that the chemical bond cleavage of various organic substances in the petroleum sludge is caused by the temperature. When the temperature is higher than $450{ }^{\circ} \mathrm{C}$, the heavy oil generated by pyrolysis undergoes the second chemical bond cleavage to generate light oil, and the gas phase residence time also increases. When the temperature is higher than $525{ }^{\circ} \mathrm{C}$, the amount of light oil and gaseous hydrocarbons is increased, and the amount of non-condensable gas generated is also increased, so that the amount of carbon generated is reduced. When the temperature continues to rise, the dehydrogenation becomes easier and the amount of $\mathrm{H}_{2}$ produced also increases.

\section{Application of different catalysts in catalytic pyrolysis of waste plastics}

Catalyst accelerates the chemical reaction without changing the result. Therefore, it is widely used in industry and research to optimize product distribution and improve product selectivity. Catalytic pyrolysis shows greater efficiency in turning plastic waste into liquid oil compared to pyrolysis and has higher consistency at lower temperatures and reaction times. ${ }^{[38,39]}$ The catalytic pyrolysis process has the following advantages: 
(1) With the participation of the catalyst, the activation energy required for the reaction is reduced, and the catalytic pyrolysis is carried out at a lower temperature, thereby increasing the conversion rate of the polymer. ${ }^{[40]}$

(2) The presence of the catalyst enhances the selectivity of the waste plastic conversion product, so that by appropriately selecting the acidity and pore structure of the catalyst, it is possible to control the different yields of the desired product (such as gases, gasoline or diesel).In addition, the development of undesirable products can be inhibited by an acceptable catalyst (such as chlorinated and brominated hydrocarbons). ${ }^{[41]}$

In the past few decades, researchers all over the world have carried out many works on the catalytic degradation of plastics and researched the catalytic efficiency and mechanism of various catalytic systems. The catalysts commonly used in catalytic pyrolysis of waste plastics mainly include: mesoporous molecular sieve catalysts, transition metal catalysts, oxide catalysts, clay mineral catalysts and other catalysts. ${ }^{[42,43]}$

\subsection{Mesoporous molecular sieve catalysts}

Mesoporous molecular sieves refer to a class of materials with ordered pore structure in the range of 2-50 nm, which have advantages of pore size can be varied in a wide range, large specific surface area, variable mesoporous morphology, optional pore wall composition and properties, and high thermal stability. ${ }^{[44]}$ As a new class of dielectric and functional materials developed under the framework of green chemistry, it mainly includes MCM-41, HZSM-5, SBA-15,Y zeolite, and has been successfully used in many chemical reactions, especially catalytic degradation of polymer materials. ${ }^{[45]}$

\subsubsection{MCM-41}

MCM-41 is a new type of nanostructured material. Unlike the traditional zeolites or other molecular sieves are synthesized by a single small organic molecule or metal ion as template,MCM-41 is based on a macromolecular surfactant as template. ${ }^{[46]}$ Jin et al..$^{[47]}$ used post-Mg-extraction Sepiolite as a raw material to synthesize a highly ordered MCM-41 mesoporous molecular sieve after hydrothermal reaction in a solution ( $\mathrm{pH} \mathrm{12)}$ at $100{ }^{\circ} \mathrm{C}$ for 24 hours. In the catalytic pyrolysis of PS, MCM-41 exhibits high catalytic activity and strong selectivity for $\mathrm{C} 5-\mathrm{C} 12$ aromatics. In addition, the yield of styrene produced $(50.7 \%)$ by PS pyrolysis with the participation of catalyst MCM-41 is much higher than that under non-catalyst condition (32.1\%).The catalytic activity of MCM-41 can be increased by the incorporation of protons or other transition metal ions. Saha et al. ${ }^{[48]}$ found that Al-MCM41 synthesized by sol-gel method is superior to hydrothermal synthesis in the catalytic cracking of PP, and Al-MCM-41 (sol-gel) has good recycling property.
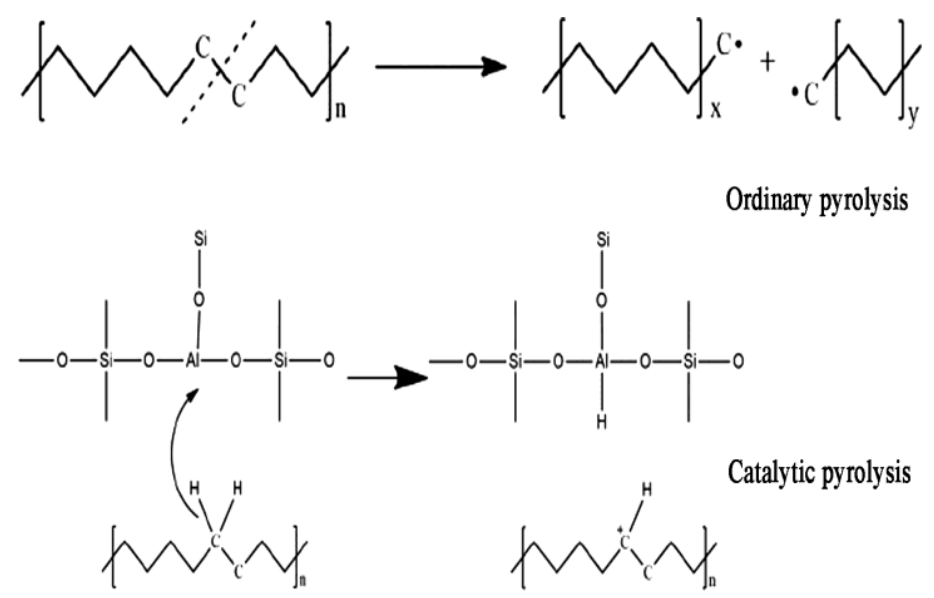

Fig. 3 Catalytic pyrolysis by HZSM-5 and ordinary pyrolysis mechanism of LDPE, reproduced with permission from [51], Copyright@Elsevier BV.

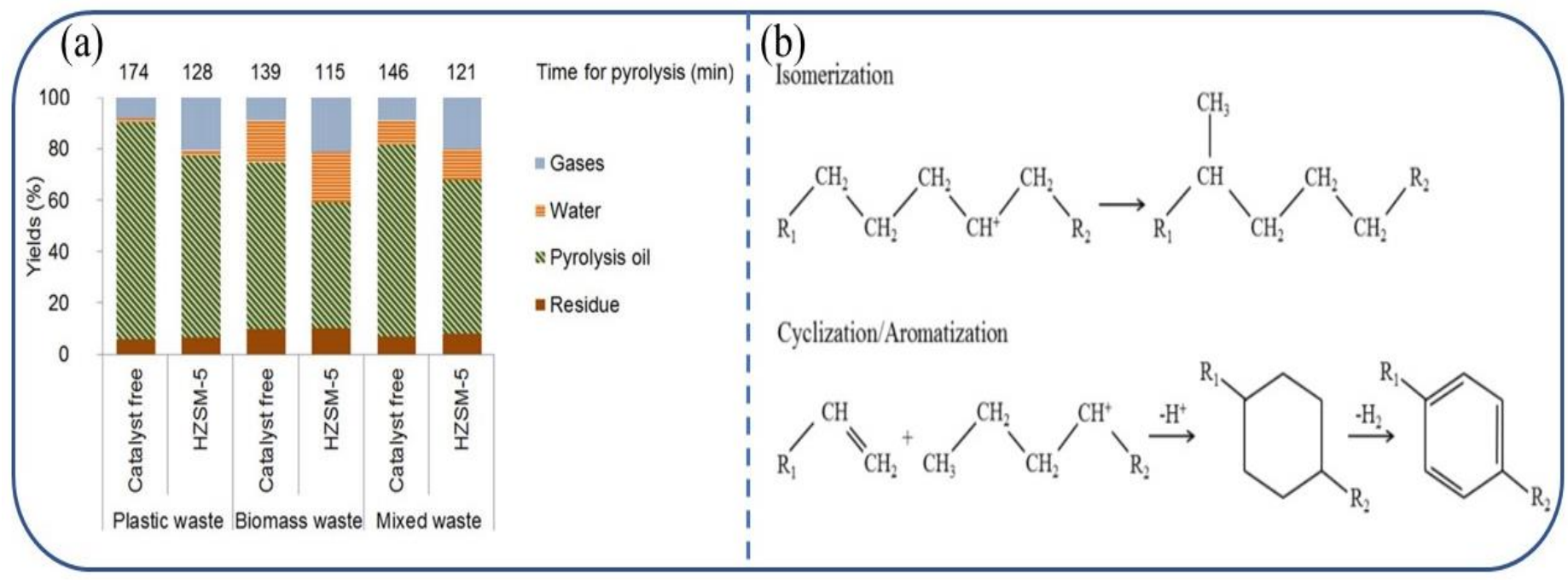

Fig. 4 Product yields (wt \%) in the batch reactor in different conditions (a) and the catalytic decomposition mechanism by HZSM-5 (b), (reprinted with the permission from [52], Copyright@Elsevier Ltd. 


\subsubsection{ZSM-5 and HZSM-5}

ZSM-5 is a new type of zeolite molecular sieve synthesized by using tripropylamine ion as a template. The stable fivemembered ring structure and high silicon-aluminum ratio determine its high thermal stability. ${ }^{[49]}$ HZSM-5 is an H-type molecular sieve obtained by ZSM-5 after repeated ammonium ion exchange treatment. ${ }^{[38]}$ ZSM-5 and HZSM-5 molecular sieves have the characteristics of unique shape selection, good hydrothermal stability, acid resistance and strong carbon deposition resistance. They are widely used in catalytic processes such as selective cracking, isomerization, alkylation and aromatization. ${ }^{[50]}$

It has been found that the fixed-bed reactor with the participation of ZSM-5 have higher polymer conversion rate and liquid yield for LDPE catalytic pyrolysis than conventional cracking. As shown in Fig. 3, the reason is that it is easier for LDPE to generate carbocations under the catalytic action of ZSM-5 than ordinary thermal decomposition to produce carbon radicals. ${ }^{[51]}$

Sebestyén et al. ${ }^{[52]}$ conducted a catalytic thermal decomposition study of HZSM-5 on a mixture of plastics (composed of PE, PP and PET) and biomass (composed of newspapers, cardboard and pine chips). In a batch reactor, the use of HZSM-5 catalyst can significantly increase the yield of volatile gases in a relatively short period of time (Fig. 4a); Aromatization or directed isomerization of the catalyst can be observed by pyrolysis-gas chromatogra-phy/mass spectrometry (Py-GC/MS) analysis (Fig. 4b).

\subsubsection{Al-SBA-15}

SBA-15 is mostly synthesized by using neutral surfactants and neutral inorganic precursors. Since there is almost no electrostatic repulsion between them, the thick pore wall can be formed inside SBA-15, which improves the thermal stability of the molecular sieve skeleton structure. SBA-15 has a strong $\mathrm{L}$ acid center and a weak $\mathrm{B}$ acid center, which determines that it is mainly used for polymer polymerization and dehydrogenation processes. ${ }^{[53]}$ The B acid center mainly acts on the catalytic cracking reaction, a large number of studies have shown that Al-SBA-15 obtained by incorporating an appropriate amount of Al can significantly increase the B acid center of SBA-15. ${ }^{[54]}$

Socci et al. ${ }^{[55]}$ synthesized a series of Al-SBA-15 catalysts with different $\mathrm{Al}$ contents and used them with ZSM-5 for catalytic cracking of LDPE. It can be seen from the derivative thermogravimetric analysis that the use of catalysts greatly reduces the thermal decomposition temperature of LDPE (Fig. 5a). In addition, Al-SBA-15 with different $\mathrm{Al}$ content has overcome the diffusion limitation of ZSM-5 in pyrolysis LDPE and exhibits high selectivity to gasoline compounds (Fig. 5b).

\subsubsection{Y zeolite}

The molar ratio of $\mathrm{SiO}_{2} / \mathrm{Al}_{2} \mathrm{O}_{3}>3$ in $\mathrm{Y}$ zeolite, and the molecular structure has a large cavity and a three-dimensional 12-element ring pore system, which can enable a variety of organic polymers to enter the cavity and undergo catalytic reaction. The primary components of waste electrical and electronic devices are high-impact polystyrene (HIPS) and acrylonitrile butadiene styrene (ABS) (WEEE). ${ }^{[5,57]}$ Muhammad et al. ${ }^{[58]}$ used Y zeolite and ZSM-5 catalysts to catalytic pyrolysis HIPS and ABS. As shown in Fig. 6, compared with ordinary pyrolysis, the yield of oil obtained by catalytic pyrolysis is reduced by $5-10 \%$, and the gas yield is correspondingly increased.

\subsection{Oxide catalysts \\ 4.2.1 $\mathrm{SiO}_{2}-\mathrm{Al}_{2} \mathrm{O}_{3}$}

$\mathrm{SiO}_{2}-\mathrm{Al}_{2} \mathrm{O}_{3}$ is a commonly used acid-catalyzed reaction catalyst. Due to its large pore size, it is widely used in the catalytic cracking reaction of waste plastics. ${ }^{[59]}$ Some studies have shown that the main products of amorphous $\mathrm{SiO}_{2}-\mathrm{Al}_{2} \mathrm{O}_{3}$ catalytic cracking LDPE are mainly gasoline (C5-C12) and intermediate fractions $(\mathrm{C} 13-\mathrm{C} 22)$ and the main products of catalytic cracking of PS are benzene, ethylbenzene and isopropyl benzene. ${ }^{[60]}$ Uddin et al. ${ }^{[61]}$ used $\mathrm{SiO}_{2}-\mathrm{Al}_{2} \mathrm{O}_{3}$ to catalytic degradation of polyethylene with different structures to refine fuel oil. All the polyethylene was cracked to produce a large number of liquid products (77-83\%), and the carbon number was mainly distributed in $\mathrm{C} 5-\mathrm{C} 12$.
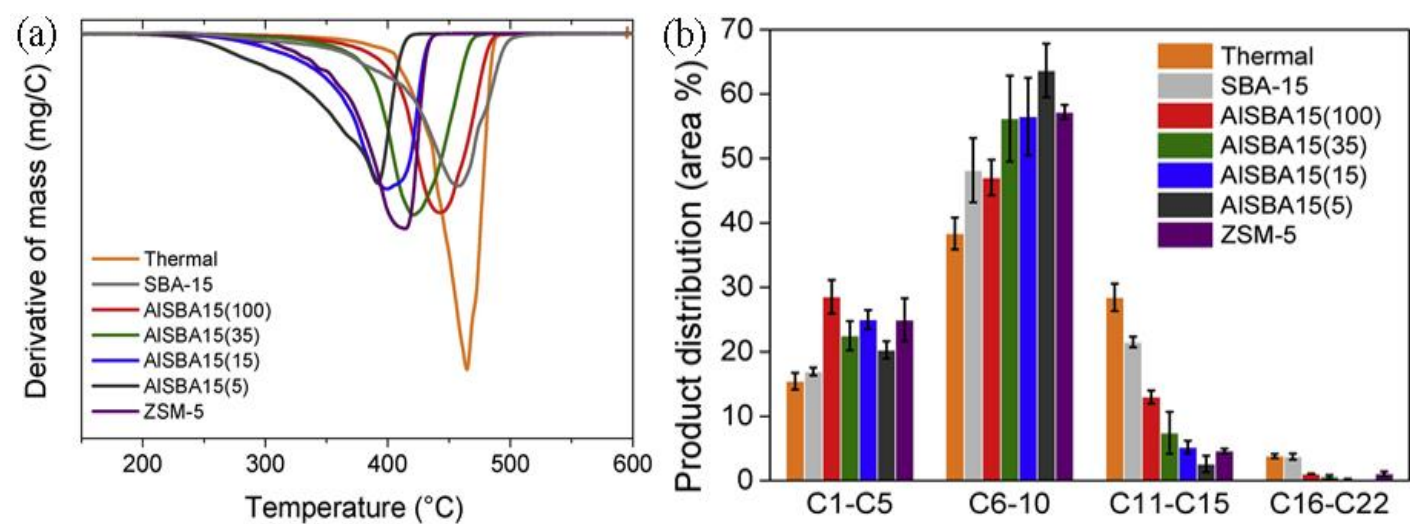

Fig. 5 Derivative thermogravimetric analysis plot of the thermal and catalytic degradation of LDPE (a) and the relative abundance of identified products from the thermal and catalytic cracking of LDPE analysed by Py-GC/MS (b), (reprinted with the permission from [55], Copyright@Elsevier BV. 


\subsubsection{Alkali metal oxide catalyst}

Alkali metal oxides are widely used in the catalytic cracking of PS. The mechanism of catalytic cracking of PS by basic catalysts is different from that of acidic catalysts. The protons of acidic catalysts attack the benzene ring and then cleave to form benzene and toluene. The alkaline metal oxide catalyst removes protons from the carbon chain to form carbanions, which then undergo beta-cleavage to form styrene. ${ }^{[62]}$

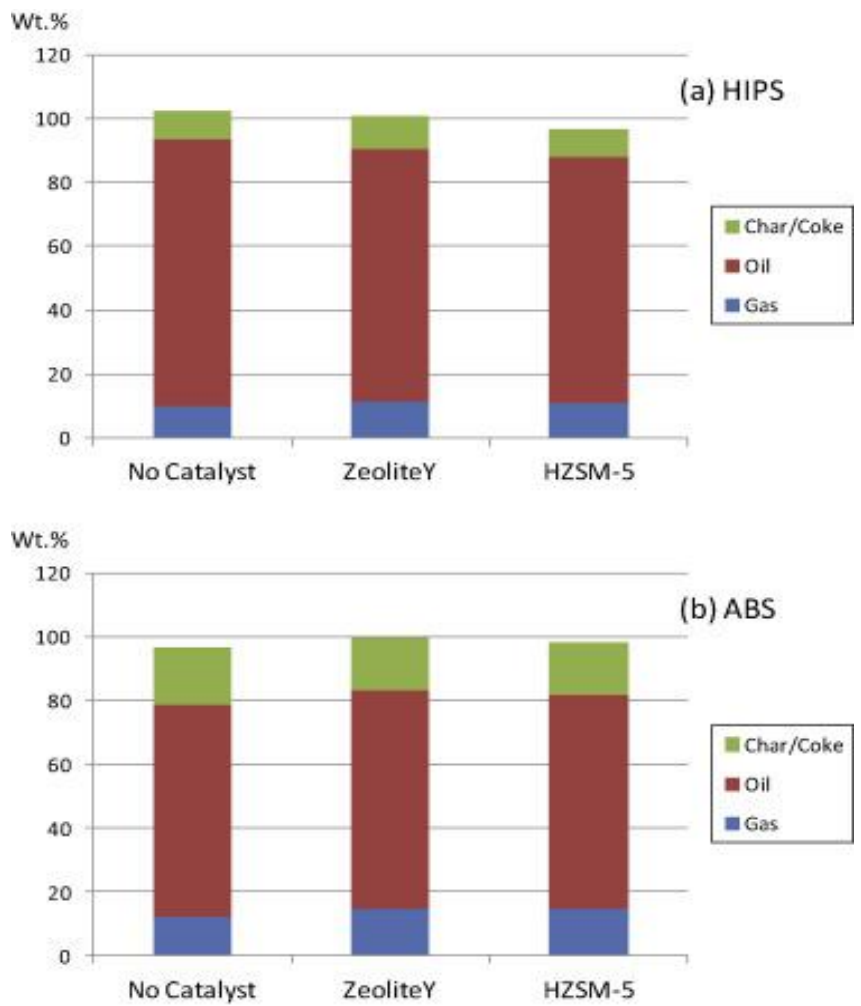

Fig. 6 Product yield from the pyrolysis and catalytic pyrolysis of HIPS and ABS plastics with zeolite Y and ZSM-5 catalysts, (reprinted with the permission from [58], Copyright@Elsevier BV.

Park et al..$^{[63]}$ demonstrated the catalytic pyrolysis of PS at $130{ }^{\circ} \mathrm{C}$ using various alkali metal oxides, the catalytic pyrolysis exhibited improved conversion and oil yield increases in catalytic pyrolysis (Table 1) in the following order: $\mathrm{BaO}>\mathrm{ZnO}>\mathrm{ZrO}_{2}>\mathrm{Al}_{2} \mathrm{O}_{3}>\mathrm{Fe}_{2} \mathrm{O}_{3}>$ thermal.

Table 1 The total oil yield and the time required to reach the total oil yield of catalytic pyrolysis PS by different alkali metal oxide catalysts at $130{ }^{\circ} \mathrm{C}$.

\begin{tabular}{ccc}
\hline Catalysts & $\begin{array}{c}\text { Total oil yield } \\
\text { (wt \%) }\end{array}$ & $\begin{array}{c}\text { Time } \\
\text { (min) }\end{array}$ \\
\hline $\mathrm{BaO}$ & 73.20 & $\sim 92$ \\
$\mathrm{ZnO}$ & 53.80 & $\sim 128$ \\
$\mathrm{ZrO}_{2}$ & 34.24 & $\sim 131$ \\
$\mathrm{Al}_{2} \mathrm{O}_{3}$ & 29.73 & $\sim 120$ \\
$\mathrm{Fe}_{2} \mathrm{O}_{3}$ & 28.73 & $\sim 90$ \\
thermal & 24.32 & $\sim 97$ \\
\hline
\end{tabular}

\subsubsection{Fly ash catalyst}

Fly ash is produced by blowing pulverized coal into the boiler at high speed with air. Among the main chemical components of fly ash, $\mathrm{SiO}_{2}, \mathrm{Al}_{2} \mathrm{O}_{3}, \mathrm{Fe}_{2} \mathrm{O}_{3}$ and $\mathrm{FeO}$ account for more than $80 \%$, and other components include $\mathrm{CaO}, \mathrm{MgO}, \mathrm{SO}_{2}, \mathrm{Na}_{2} \mathrm{O}$ and $\mathrm{K}_{2} \mathrm{O}$. Fly ash is used as a catalyst for catalytic cracking or catalytic upgrading of waste plastics, which can realize the comprehensive recycling of waste plastics and fly ash. ${ }^{[64,65]}$

Gaurh et $a l^{[66]}$ used fly ash (FA) as raw material to synthesize catalysts (FA, FA-600, FA-700, FA-800 and FA900 ) at different temperatures. The catalyst effectively produced valuable aromatic hydrocarbons such as benzene, toluene, ethyl benzene and xylene (BTEX) from waste PE. Catalytic thermal decomposition results indicate that FA-800 exhibits excellent selectivity to BTEX, which may be attributed to FA-800 having a larger specific surface area and a larger Si/Al molar ratio (Table 2).

Table 2 Surface area, pore volume and (Si/Al) ratio of FA based catalysts.

\begin{tabular}{cccc} 
Catalysts & $\begin{array}{c}\text { Surface area } \\
\left(\mathbf{m}^{2} / \mathbf{g}\right)\end{array}$ & $\begin{array}{c}\text { Pore volume } \\
(\mathbf{m l} / \mathbf{g})\end{array}$ & Si/Al \\
\hline FA & 1.74 & 2.25 & 2.18 \\
FA-600 & 10.98 & 14.19 & 3.32 \\
FA-700 & 25.95 & 19.34 & 5.22 \\
FA-800 & 310.40 & 43.95 & 16.03 \\
FA-900 & 5.78 & 59.28 & 1.43 \\
\hline
\end{tabular}

\subsection{Transition metal and metal-based catalysts}

\subsubsection{Transition metal catalyst}

Transition metals such as $\mathrm{Fe}$, Co and $\mathrm{Ni}$ etc. are not only widely used in the field of inorganic catalysis, but also have great value in the field of organic polymer catalytic pyrolysis. ${ }^{[67]}$ Miskolczi et al. ${ }^{[68]}$ studied the catalytic pyrolysis of waste plastics in municipal solid waste by using Ni-Mo catalyst and zeolite at $500{ }^{\circ} \mathrm{C}$. The results show that the product of the zeolite catalyst is mainly olefin, and the Ni-Mo catalyst has a significant promoting effect on the formation of cyclic hydrocarbons.

Mishra et al. ${ }^{[69]}$ used metal Ni as catalyst to prepare highvalue carbon nanotubes (CNTs) by catalytic cracking of waste $\mathrm{PP}$ at $600-800{ }^{\circ} \mathrm{C}$ by chemical vapor deposition. The results show that the prepared CNTs have an average diameter of about $20 \mathrm{~nm}$, a length of 10-100 $\mu \mathrm{m}$, and a yield of about $20 \mathrm{wt} \%$. The prepared CNTs can transmit up to $85 \%$ of visible light at $550 \mathrm{~nm}$, which indicating that it can be used in optoelectronic devices.

\subsubsection{Metal-based catalysts}

The metal-based catalyst enhances the catalytic effect of the original catalyst by means of metal doping. Miskolczi et al. ${ }^{[70]}$ modified ZSM-5 and Y-zeolite with different metals. During the degradation of domestic plastic waste, as shown in Fig. 7, 
it was found that the catalyst can reduce the activation energy of thermal decomposition, and the activation energy of ZSM5 and Y-type zeolite catalysts could be reduced in the same order: $\mathrm{Cu}<\mathrm{Ce}<\mathrm{Mg}<\mathrm{Ni}<\mathrm{Fe}$ (III) $<\mathrm{Fe}$ (II) $<\mathrm{Zn}<\mathrm{Sn}$. It is worth mentioning that compared with the ZSM-5 based catalysts, the reduction of activation energy by using Y-zeolite catalyst is more significant.

\subsection{Clay mineral catalyst}

Clay is an important mineral raw material consisting of a number of hydrated silicates and a number of alkali metal oxides, alumina, and alkaline earth metal oxides, as well as mica, feldspar, carbon, sulphide, sulphate, quartz, and other impurities. ${ }^{[71]}$ Clay catalyst has mild acidity, which can prevent excessive cracking and generate more liquid hydrocarbon during catalytic pyrolysis. ${ }^{[72]}$ Manos et al. ${ }^{[73]}$ compared the catalytic effect of natural clay and Y zeolite on PE at higher temperatures. The results show that the weak acid natural clay catalyst exhibits stronger catalytic activity than $\mathrm{Y}$ zeolite, and its liquid recovery rate reaches $70 \%$.

\section{Application of different catalysts in pyrolysis of petroleum sludge}

Worldwide, due to the continuous exploitation of crude oil and the increasing demand for light fuel oil, the energy crisis is more and more prominent. In order to alleviate this problem and broaden the production raw materials of low-carbon olefins, it has become a research hotspot to develop and utilize the heavy oil such as petroleum sludge as raw material and to directly produce low-carbon olefins by catalytic cracking process. ${ }^{[74,75]}$

\subsection{Mesoporous molecular sieve catalysts}

The superior physicochemical properties of molecular sieve catalysts not only make them commonly used in waste plastic catalytic pyrolysis, but also in petroleum sludge catalytic pyrolysis. ${ }^{[76]}$ Silva et al. ${ }^{[77]}$ studied the thermal decomposition products of petroleum sludge in the presence or absence of $Y$ zeolite catalyst. It was found that Y zeolite catalyst can better distribute Liquid Petroleum Gas (LPG) products-gasoline and diesel at different temperatures (Fig. 8).Though a series of experiments, Milato et al. ${ }^{[78]}$ showed that the use of molecular sieve catalysts increased the production of light hydrocarbons and decreased the production of aromatic compounds from petroleum sludge oil in pure pyrolysis oil.

\subsection{M-series catalyst ( $\mathrm{M}=\mathrm{Al}, \mathrm{Fe}, \mathrm{Ca}, \mathrm{Na}, \mathrm{K})$}

Based on domestic and international research, this type of catalyst mainly includes iron compounds $\left(\mathrm{Fe}, \mathrm{Fe}_{2} \mathrm{O}_{3}, \mathrm{FeCl}_{3}\right.$, $\mathrm{Fe}_{2}\left(\mathrm{SO}_{4}\right)_{3} \bullet \mathrm{nH}_{2} \mathrm{O}$ and $\left.\mathrm{FeSO}_{4} \bullet 7 \mathrm{H}_{2} \mathrm{O}\right)$, aluminum compounds $\left(\mathrm{Al}, \mathrm{Al}_{2} \mathrm{O}_{3}\right.$ and $\left.\mathrm{AlCl}_{3}\right)$, calcium compounds $\left(\mathrm{CaO}, \mathrm{Ca}(\mathrm{OH})_{2}\right.$, $\mathrm{CaCl}_{2}$, and $\mathrm{CaCO}_{3}$ ), sodium compounds (such as $\mathrm{NaCl}$, $\mathrm{Na}_{2} \mathrm{CO}_{3}$ and $\mathrm{NaOH}$ ) and potassium compounds (i.e. $\mathrm{K}_{2} \mathrm{CO}_{3}$, $\mathrm{KOH}$, and $\mathrm{KCl}$ ). Shie et al. ${ }^{[79-85]}$ conducted a comprehensive study on the catalytic pyrolysis petroleum sludge of this type of catalyst. The results show that the order of influence of different catalysts on the quality of pyrolysis oil is $\mathrm{Fe}_{2} \mathrm{O}_{3}>$ $\mathrm{Fe}_{2}\left(\mathrm{SO}_{4}\right)_{3} \bullet \mathrm{nH}_{2} \mathrm{O}>\mathrm{Al}>\mathrm{FeSO}_{4} \cdot 7 \mathrm{H}_{2} \mathrm{O}>\mathrm{Al}_{2} \mathrm{O}_{3}>\mathrm{Fe}>\mathrm{FeCl}_{3}>$ $\mathrm{AlCl}_{3}>\mathrm{CaO}>\mathrm{Ca}(\mathrm{OH})_{2}>\mathrm{CaCO}_{3}>\mathrm{CaCl}_{2}>\mathrm{KOH}>\mathrm{KCl}>$ $\mathrm{K}_{2} \mathrm{CO}_{3}>\mathrm{NaOH}>\mathrm{Na}_{2} \mathrm{CO}_{3}>\mathrm{NaCl}$.

\section{Catalytic cracking mechanism}

The catalysts used for waste plastics and petroleum sludge can be basically divided into acidic catalysts and basic catalysts, so the catalytic pyrolysis mechanism should also be considered from these two aspects. ${ }^{[86]}$

(1) The thermal pyrolysis process under the action of solid acid catalyst is considered to be a carbocations mechanism. ${ }^{[87]}$ The waste polymer materials are first pyrolyzed to produce a long carbon chain olefin. The olefin then obtains $\mathrm{H}^{+}$from the catalyst surface to form a carbocation, and the carbocation preferentially breaks into a small molecular hydrocarbon containing primary and secondary carbon ions at the $\beta$ position, and then isomerized to a more stable tertiary carbon ion. ${ }^{[88]}$ Finally, the stable tertiary carbon ion returns $\mathrm{H}^{+}$to the catalyst, and turns itself into an olefin and other more useful hydrocarbons. ${ }^{[89]}$

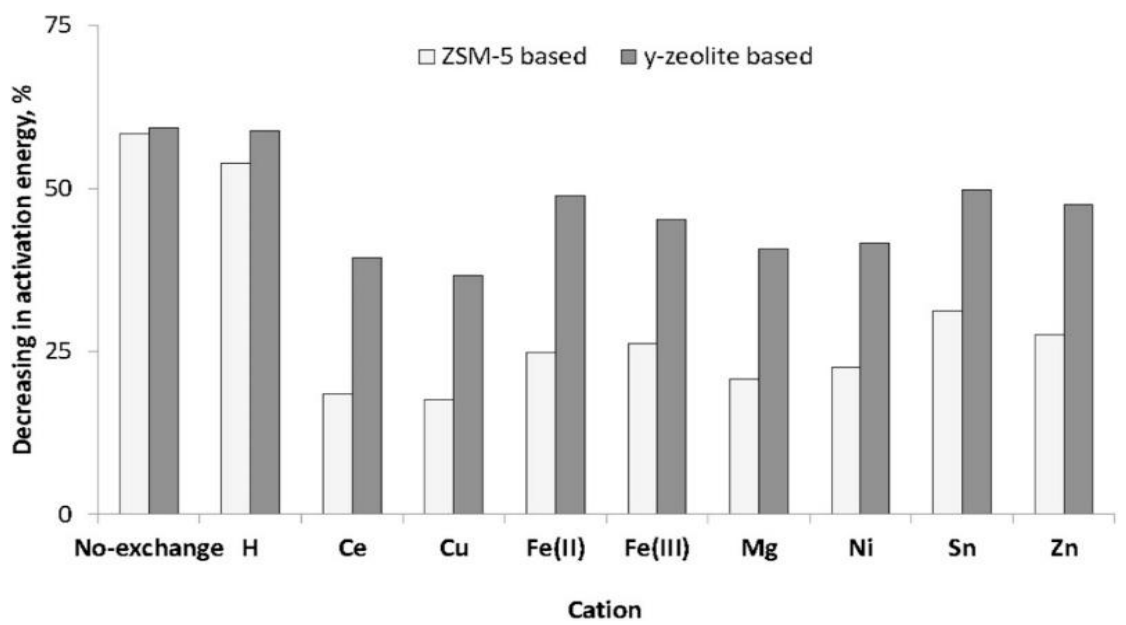

Fig. 7 Catalyst efficiency in apparent activation energy decreasing, reproduced with permission from [70], Copyright@Elsevier Limited. 

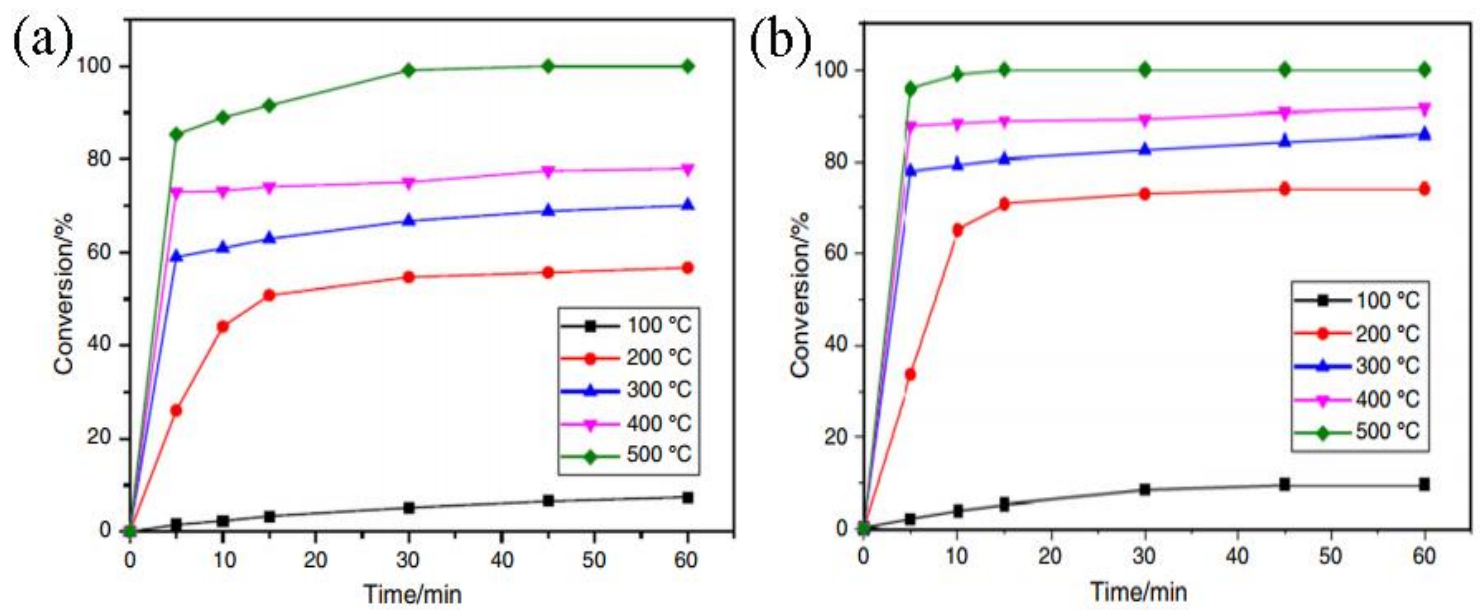

Fig. 8 Thermal and thermocatalytic degradation of petroleum sludge with (a) or without (b) Y zeolite catalyst, at different temperatures and times, reproduced with permission from [77], Copyright 2011, Elsevier.

(2) The basic catalyst mainly acts on hydrocarbons containing benzene rings. The catalytic pyrolysis mechanism of the basic catalyst is different from that of the acidic catalyst. The alkaline catalyst will remove the protons on the carbon chain to form negative carbon ions, and then the $\beta$-bit breakage will occur to form small molecules of hydrocarbons such as styrene and other useful hydrocarbons. ${ }^{[90,91]}$

\section{Concluding remarks and future works}

The extraction and processing of petroleum has brought tremendous changes to the world. However, the disposal of waste plastics and oily solid waste-petroleum sludge derived from it are faced with huge challenges. Many of the plastic items discarded are not biodegradable, placing immense pressure on the environment and on the government. Petroleum sludge contains a large number of malodorous toxic substances (such as benzene, phenols, anthracene, pyrene, etc.), heavy metals, polychlorinated biphenyls, dioxins and other radioactive nuclear elements. Traditional treatment methods (such as landfill and incineration) not only waste resources and cause secondary damage to the environment, but also contradict the concept of green sustainable development. Catalytic cracking is currently a relatively mature and effective method for the treatment of waste organic polymer waste. This work provides a comprehensive overview of the relevant catalysts used in catalytic cracking and the current research progress.

Although the world's research on waste plastics is already in a hot stage, there is still a long way to go and still face enormous challenges ${ }^{[92,93]}$ The further tasks are:

i) The next step is to continuously optimize the experimental conditions of catalytic cracking and achieve the double harvest of social and economic benefits on the basis of reducing the recovery cost. ${ }^{[94]}$

ii) Nowadays, the world is a global village. The treatment and use of waste plastics and petroleum sludge for recycling is not only a waste disposal problem, but also closely linked to energy and the global environment. Communication, understanding and collaborative efforts to optimize the climate and support future generations should be enhanced by countries. ${ }^{[95]}$

iii) Future research and technological innovation should be taken into comprehensive consideration from the perspectives of environmental protection and energy recovery. The adoption of harmless and resource-based core treatment technologies is the only way for the sustainable development of all countries. Therefore, it is necessary to make systematic planning and pay more attention to its investment. ${ }^{[96]}$

\section{Acknowledgements}

We acknowledge for the financial support from National Natural Science Foundation of China (21704096, 51703217) and the China Postdoctoral Science Foundation (Grant no. 2019M662526).

\section{Supporting information}

Not applicable.

\section{Conflict of interest}

There are no conflicts to declare.

\section{References}

[1] C. Yin, X. Zhao, J. Zhu, H. Hu, M. Song, S. Wu, J. Mater. Sci., 2019, 54, 3960-3974, doi: 10.1007/s10853-018-3134-2.

[2] E. Dhanumalayan, G.M. Joshi, Adv. Compos. Hybrid Mater., 2018, 1, 247-68, doi: 10.1007/s42114-018-0023-8.

[3] N. Fan, L. Yuguo, T. Kun, W. Baichun, Z. Mingdong, R. Wen, X. Shuixiang, L. Xingchun, Fuel, 2020, 278, 118332, doi: 10.1016/j.fuel.2020.118332.

[4] D. Pan, F. Su, C. Liu, Z. Guo, Adv. Compos. Hybrid Mater, 2020, 3, 443-461, doi: 10.1007/s42114-020-00190-0.

[5] R. Ahamed, S. Hossain, M. Haque, S.A. Iqbal, Int. J. Sust. Eng., 2020, 13, 252 doi: 10.1080/19397038.2020.1848125. 
[6] S. Sikdar, A. Siddaiah, P.L. Menezes, Lubricants, 2020, 8, 78 doi: 10.3390/lubricants 8080078 .

[7] S.J. Barnes, Environ Pollut., 2019, 249, 812-821, doi: 10.1016/j.envpol.2019.03.108.

[8] E.L. Petrun Sayers, A.M. Parker, R. Ramchand, M.L. Finucane, V. Parks, R. Seelam, Am. J. Disaster Med., 2019, 14, 121-136, doi: 10.5055/ajdm.2019.0323.

[9] A.M. Memon, M.H. Sutanto, M. Napiah, M.I. Khan, W. Rafiq, Constr. Build. Mater, 2020, 264, 120701, doi: 10.1016/j.conbuildmat.2020.120701.

10] A. Gielnik, Y. Pechaud, D. Huguenot, A. Cebron, G. Esposito, E.D. van Hullebusch, J. Environ. Manage., 2020, 111648-111648, doi: 10.1016/j.jenvman.2020.111648.

[11] S. Varjani, A. Pandey, V.N. Upasani, Sci. Total Environ., 2020, 776, 142934-142934,

10.1016/j.scitotenv.2020.142934.

[12] Y. Su, Z. Zhang, D. Wu, L. Zhan, H. Shi, B. Xie, Water Res., 2019, 164, 114968, doi: 10.1016/j.watres.2019.114968.

[13] Z. Tang, Q. Huang, Y. Yang, Z. Nie, J. Cheng, J. Yang, Y. Wang, M. Chai, Environ. Sci. Pollut. Res., 2016, 23, 625-637, doi: 10.1007/s11356-015-5296-7.

[14] B. Wucher, F. Lani, T. Pardoen, C. Bailly, P. Martiny, Compos. Part A, 2014, 56, 27-35, doi: 10.1016/j.compositesa.2013.09.010.

[15] D. Briassoulis, M. Hiskakis, E. Babou, Waste Manage., 2013, 33, 1516-1530, doi: 10.1016/j.wasman.2013.03.004.

[16] K. Ragaert, L. Delva, K. Van Geem, Waste Manage., 2017, 69, 24-58, doi: 10.1016/j.wasman.2017.07.044.

[17] G. Yan, X. Jing, H. Wen, S. Xiang, Energ. Fuel., 2015, 29, 2289-2298, doi: 10.1021/ef502919f.

[18] M. Gear, J. Sadhukhan, R. Thorpe, R. Clift, J. Seville, M. Keast, J. Clean. Product., 2018, 180, 735-747, doi: 10.1016/j.jclepro.2018.01.015.

[19] A.F. Anene, S.B. Fredriksen, K.A. Saetre, L.-A. Tokheim, Sustainability, 2018, 10, 3979, doi: 10.3390/su10113979.

[20] S.L. Wong, N. Ngadi, T.A.T. Abdullah, I.M. Inuwa, Renew. Sust. Energ. Rev., 2015, 50, 1167-1180, doi: 10.1016/j.rser.2015.04.063.

[21] J. Gong, J. Liu, Z. Jiang, J. Feng, X. Chen, L. Wang, E. Mijowska, X. Wen, T. Tang, Appl. Catal. B., 2014, 147, 592-601, doi: 10.1016/j.apcatb.2013.09.044.

[22] A.S. Luyt, S.A. Gasmi, S.S. Malik, R.M. Aljindi, M. Ouederni, S.N. Vouyiouka, A.D. Porfyris, R. Pfaendner, C.D. Papaspyrides, Express Polym. Lett., 2021, 15, 121-136, doi: 10.3144/expresspolymlett.2021.12.

[23] A.R. Torun, S.H. Kaya, N. Choupani, Green Mater., 2020, 8, 194-202, doi: 10.1680/jgrma.19.00062.

[24] A.H. Awad, R. El-Gamasy, A.A. Abd El-Wahab, M.H. Abdellatif, Ain Shams Eng. J., 2020, 11, 1211-1217, doi: 10.1016/j.asej.2020.02.001.

[25] K. Mazur, P. Jakubowska, P. Romanska, S. Kuciel, Compos. Part B, 2020, 202, doi: 10.1016/j.compositesb.2020.108399.

[26] S.M. Al-Salem, Process Saf. Environ., 2019, 127, 171-179, doi: 10.1016/j.psep.2019.05.008.
[27] L. Tang, C. Su, Y. Chen, Y. Xian, X. Hui, Z. Ye, M. Chen, F. Zhu, H. Zhong, J. Hazard. Mater., 2021, 401, 123337-123337, doi: 10.1016/j.jhazmat.2020.123337.

[28] N. Miskolczi, L. Bartha, A. Angyal, Energ. Fuel., 2009, 23, 2743-2749, doi: 10.1021/ef8011245.

[29] J. R. Rodriguez, P.J. Kim, K. Kim, Z. Qi, H. Wang, V.G. Pol, J. Colloid Interf. Sci., 2021, 583, 362-370, doi: 10.1016/j.jcis.2020.09.009.

[30] I. Ahmad, M.I. Khan, H. Khan, M. Ishaq, R. Tariq, K. Gul, W. Ahmad, Int. J. Green Energy, 2015, 12, 663-671, doi: 10.1080/15435075.2014.880146.

[31] H.M. Abomostafa, J. Mol. Struct., 2021, 1225, doi: 10.1016/j.molstruc.2020.129126.

[32] J. A. Onwudili, N. Insura, P.T. Williams, J. Anal. Appl. Pyrol., 2009, 86, 293-303, doi: 10.1016/j.jaap.2009.07.008.

[33] J. A. Onwudili, Fuel, 2016, 181, 157-169, doi: 10.1016/j.fuel.2016.04.102.

[34] H. Gu, H. Zhang, C. Gao, C. Lian, J. Gu, Z. Guo, ES Mater. Manuf., 2018, 1, 3-12, doi: 10.30919/esmm5f108.

[35] T. Chorazy, J. Caslavsky, V. Zvakova, J. Racek, P. Hlavinek, Waste Biomass Valori., 2020, 11, 4491-4505, doi: 10.1007/s12649-019-00735-5.

[36] L. Bai, S. Zheng, R. Bao, Z. Liu, M. Yang, W. Yang, ES Mater. Manuf., 2018, 3, 66, doi: 10.30919/esmm5f195.

[37] F.-T. Shen, M.-J. Ho, H.-R. Huang, A.B. Arun, P.D. Rekha, C.-C. Young, Res. Microbiol., 2008, 159, 522-529, doi: 10.1016/j.resmic.2008.07.004.

[38] X. Lin, L. Kong, X. Ren, D. Zhang, H. Cai, H. Lei, Renew. Energ., 2021, 164, 87-95, doi: 10.1016/j.renene.2020.09.071.

[39] T. Zhang, X. Mao, J. Qu, Y. Liu, A.A. Siyal, W. Ao, J. Fu, J. Dai, Z. Jiang, Z. Deng, Y. Song, D. Wang, C. Polina, J. Hazard. Mater., 2021, 402, doi: 10.1016/j.jhazmat.2020.123749.

[40] Y. Wang, Q. Yang, L. Ke, Y. Peng, Y. Liu, Q. Wu, X. Tian, L. Dai, R. Ruan, L. Jiang, Fuel, 2021, 283, doi: 10.1016/j.fuel.2020.119170.

[41] S. Cheng, Q. Zhang, J. Shu, H. Xia, L. Zhang, J. Peng, G. Lin, W. Hu, Q. Chen, Environ. Prog. Sustain. Energy, 2020, 39, doi: 10.1002/ep.13452.

[42] J. Ye, C. Li, Y. Yan, J. Taiwan Inst. Chem. Eng., 2020, 112, 202-211, doi: 10.1016/j.jtice.2020.07.001.

[43] L. Zhu, D. Zheng, Z. Wang, X. Zheng, P. Fang, J. Zhu, M. Yu, Y. Tong, X. Lu, Adv. Mater, 2018, 30, doi: 10.1002/adma.201805268.

[44] F. Yang, L. Zhou, S. Gao, X. Wang, J. Chen, A. Yuan, E.H. Ang, J. Alloy. Compod., 2020, 844, doi: 10.1016/j.jallcom.2020.156137.

[45] S. Yu, Y. Li, Q. Chen, L. Li, X. Ge, H. Li, Powder Technol., 2020, 375, 533-538, doi: 10.1016/j.powtec.2020.07.073.

[46] V.M. Vaschetti, G.A. Eimer, A.L. Canepa, S.G. Casuscelli, Micropor. Mesopor. Mater., 2021, 311, doi: 10.1016/j.micromeso.2020.110678.

[47] S. Jin, K. Cui, H. Guan, M. Yang, L. Liu, C. Lan, Appl. Clay Sci., 2012, 56, 1-6, doi: 10.1016/j.clay.2011.11.012.

[48] B. Saha, P. Chowdhury, A. K. Ghoshal, Appl. Catal. B, 2008, 83, 265-276, doi: 10.1016/j.apcatb.2008.02.021. 
[49] Q. Bu, M. Cao, M. Wang, X. Zhang, H. Mao, Sci. Total Environ., 2021, $\quad \mathbf{7 5 4}, \quad 142174, \quad$ doi: 10.1016/j.scitotenv.2020.142174.

[50] X.-G. Li, X. Huang, Y.-L. Zhang, H. Li, W.-D. Xiao, Z. Wei, Chem. Eng. Sci., 2020, 226, doi: 10.1016/j.ces.2020.115859.

[51] A.L. Figueiredo, A.S. Araujo, M. Linares, A. Peral, R.A. Garcia, D.P. Serrano, V.J. Fernandes, Jr., J. Anal. Appl. Pyrol., 2016, 117, 132-140, doi: 10.1016/j.jaap.2015.12.005.

[52] Z. Sebestyen, E. Barta-Rajnai, J. Bozi, M. Blazso, E. Jakab, N. Miskolczi, J. Soja, Z. Czegeny, Appl. Energ., 2017, 207, 114 122, doi: 10.1016/j.apenergy.2017.06.032.

[53] J. Wang, L. Wang, X. Cai, B. Karmakar, M.M. Zangeneh, H. Liu, Mater. Chem. Phys., 2021, 257, doi: 10.1016/j.matchemphys.2020.123375.

[54] S. Wang, Z. Li, W. Yi, P. Fu, A. Zhang, X. Bai, Renew. Energ., 2021, 163, 1673-1681, doi: 10.1016/j.renene.2020.10.108.

[55] J. Socci, A. Osatiashtiani, G. Kyriakou, T. Bridgwater, Appl. Catal.A-Gen., 2019, 570, 218-227, doi: 10.1016/j.apcata.2018.11.020.

[56] S. Yu, J. Yan, W. Lin, J. Zhang, J. Long, Catal. Commun., 2021, 148, 106171, doi: 10.1016/j.catcom.2020.106171.

[57] L. Yan, Y. Liu, P. Lv, M. Wang, F. Li, W. Bao, J. Energy Inst., 2020, 93, 2247-2254, doi: 10.1016/j.joei.2020.06.007.

[58] C. Muhammad, J.A. Onwudili, P.T. Williams, J. Anal. Appl. Pyrol., 2015, 113, 332-339, doi: 10.1016/j.jaap.2015.02.016.

[59] D. Pan, S. Ge, J. Zhao, J. Tian, Q. Shao, L. Guo, X. Mai, T. Wu, V. Murugadoss, H. Liu, T. Ding, S. Angaiah, Z. Guo, Ind. Eng. Chem. Res., 2019, 58, 836-848, doi: 10.1021/acs.iecr.8b04829.

[60] H. Wang, Y. Wu, S. Guo, C. Dong, M. Ding, Mol. Catal., 2020, 497, 111218, doi: 10.1016/j.mcat.2020.111218.

[61] S. Uddin, M. Mirnezami, J.A. Finch, Colloid. Surface. A, 2010, 371, 64-70, doi: 10.1016/j.colsurfa.2010.09.004.

[62] A. Kaur, A. Ali, Ind. Eng. Chem. Res., 2020, 59, 2667-2679, doi: 10.1021/acs.iecr.9b05747.

[63] J.J. Park, K. Park, J.S. Kim, S. Maken, H. Song, H. Shin, J.W. Park, M.J. Choi, Energ. Fuel., 2003, 17, 1576-1582, doi: 10.1021/ef0301021.

[64] E.M. Vargas, L. Ospina, M.C. Neves, L.A.C. Tarelho, M.I. Nunes, Renew. Energ., 2021, 163, 1637-1647, doi: 10.1016/j.renene.2020.10.030.

[65] D. Pan, S. Ge, J. Zhao, Q. Shao, L. Guo, X. Zhang, J. Lin, G. $\mathrm{Xu}, \quad$ Z. Guo, Dalton T., 2018, 47, 9765-9778, doi: $10.1039 / \mathrm{c} 8 \mathrm{dt} 01045 \mathrm{e}$.

[66] P. Gaurh, H. Pramanik, Waste Manage., 2018, 77, 114-130, doi: 10.1016/j.wasman.2018.05.013.

[67] R. Breglia, F. Arrigoni, M. Sensi, C. Greco, P. Fantucci, L. De Gioia, M. Bruschi, Inorg. chem., 2021, 60, 387-402, doi: 10.1007/978-981-15-6887-9 15.

[68] N. Miskolczi, F. Ates, J. Anal. Appl. Pyrol., 2016, 117, 273281, doi: 10.1016/j.jaap.2015.11.005.

[69] N. Mishra, G. Das, A. Ansaldo, A. Genovese, M. Malerba, M. Povia, D. Ricci, E. Di Fabrizio, E. Di Zitti, M. Sharon, M. Sharon, J. Anal. Appl. Pyrol., 2012, 94, 91-98, doi: 10.1016/j.jaap.2011.11.012.
[70] N. Miskolczi, T. Juzsakova, J. Soja, J. Energy Inst., 2019, 92, 118-127, doi: 10.1016/j.joei.2017.10.017.

[71] V. M. A. Magalhaes, G.P. Mendes, J.D.B. Costa-Filho, R. Cohen, C.S.M. Partiti, M.M.G.R. Vianna, O. Chiavone-Filho, J. Environ. Chem. Eng., 2020, 8, doi: 10.1016/j.jece.2019.103568.

[72] D. Chen, J. Feng, J. Sun, C. Cen, S. Tian, J. Yang, Y. Xiong, J. Chem. Technol. Biot., 2020, 95, 1441-1452, doi: $10.1002 /$ jctb.6329.

[73] G. Manos, I.Y. Yusof, N. Papayannakos, N.H. Gangas, Ind. Eng. Chem. Res., 2001, 40, 2220-2225, doi: 10.1021/ie001048o. [74] X.-F. Chen, Z.-J. Da, J.-H. Gong, H.-J. Zhang, Y.-K. Zhu, J.Y. Yang, P.-Q. Yuan, W.-K. Yuan, Aiche J., 2021, 67, doi: 10.1002/aic. 17086.

[75] J.-X. Wang, L.-L. Wang, T.-F. Wang, X.-Q. Peng, Petrol. Sci. Technol., 2020, 38, 945-954, doi: 10.1080/10916466.2020.1804935.

[76] D. Pan, S. Ge, J. Tian, Q. Shao, L. Guo, H. Liu, S. Wu, T. Ding, Z. Guo, Chem. Rec., 2020, 20, 355-369, doi: 10.1002/tcr.201900046.

[77] B. Silva, H. Figueiredo, V.P. Santos, M.F.R. Pereira, J.L. Figueiredo, A.E. Lewandowska, M.A. Banares, I.C. Neves, T. Tavares, J. Hazard. Mater, 2011, 192, 545-553, doi: 10.1016/j.jhazmat.2011.05.056.

[78] J.V. Milato, R.J. Franca, M.R.C. Marques Calderari, J. Environ. Chem. Eng., 2020, 8, doi: 10.1016/j.jece.2020.103805.

[79] J.-L. Shie, C.-C. Chang, C.-Y. Chang, C.-C. Tzeng, C.-Y. Wu, K.-L. Lin, J.-Y. Tseng, M.-H. Yuan, H.-Y. Li, C.-H. Kuo, Y.-J. Yu, L.-C. Chang, Bioresource Technol., 2011, 102, 11011-11017, doi: 10.1016/j.biortech.2011.07.097.

[80] J.-L. Shie, F.-J. Tsou, K.-L. Lin, C.-Y. Chang, Bioresource Technol., 2010, 101, 761-768, doi: 10.1016/j.biortech.2009.08.072.

[81] J.-L. Shie, C.-Y. Chang, W.-K. Tu, Y.-C. Yang, J.-K. Liao, C.-C. Tzeng, H.-Y. Li, Y.-J. Yu, C.-H. Kuo, L.-C. Chang, Energ. Fuel., 2008, 22, 75-82, doi: 10.1021/ef700301v.

[82] J.L. Shie, J.P. Lin, C.Y. Chang, S.M. Shih, D.J. Lee, C.H. Wu, J. Anal. Appl. Pyrol., 2004, 71, 695-707, doi: 10.1016/j.jaap.2003.10.001.

[83] J.L. Shie, J.P. Lin, C.Y. Chang, D.J. Lee, C.H. Wu, Resour. Conserv. Recy., 2003, 39, 51-64, doi: 10.1016/s09213449(02)00120-9.

[84] J.L. Shie, C.Y. Chang, J.P. Lin, D.J. Lee, C.H. Wu, Energ. Fuel., 2002, 16, 102-108, doi: 10.1021/ef0100810.

[85] J.L. Shie, Y.H. Chen, C.Y. Chang, J.P. Lin, D.J. Lee, C.H. Wu, Energ. Fuel., 2002, 16, 109-118, doi: 10.1021/ef010082s.

[86] Z. Chen, X. Zhang, F. Yang, H. Peng, X. Zhang, S. Zhu, L. Che, Appl. Catal. a-Gen., 2021, 609, 117873, doi: 10.1016/j.apcata.2020.117873.

[87] R. Li, H. Yan, Y. Dang, Y. Liu, X. Feng, X. Chen, X. Jin, C. Yang, Mol. Catal., 2019, 479, 17-26, doi: 10.1016/j.mcat.2019.110588.

[88] Z. Chen, F. Gao, K. Ren, Q. Wu, Y. Luo, H. Zhou, M. Zhang, Q. Xu, Rsc Adv., 2018, 8, 3392-3398, doi: 10.1039/c7ra12629h.

[89] J. Weitkamp, Chemcatchem, 2012, 4, 292-306, doi: $10.1002 /$ cctc. 201100315. 
[90] C. Li, L. Zhang, M. Gholizadeh, R. Westernhof, Z. Cui, B. Liu, Y. Tang, X. Jin, Z. Xu, X. Hu, Energ. Fuel., 2020, 34, $11026-$ 11040, doi: 10.1021/acs.energyfuels.0c01794.

[91] B. Valle, N. Garcia-Gomez, A. Remiro, A.G. Gayubo, J. Bilbao, Fuel Process. Technol., 2019, 195, doi: 10.1016/j.fuproc.2019.106142.

[92] A. Pathak, R. Kothari, M. Vinoba, N. Habibi, V.V. Tyagi, J. environ. manage, 2020, 280, 111789-111789, doi: 10.1016/j.jenvman.2020.111789.

[93] R. Palos, A. Gutierrez, M.L. Fernandez, M.J. Azkoiti, J. Bilbao, J.M. Arandes, Ind. Eng. Chem. Res., 2020, 59, 1686816875, doi: 10.1021/acs.iecr.0c03257.

[94] Q. Chen, J. Ding, T. Chai, Q. Pan, IEEE T. Cybernetics, 2020, 1-14, doi: 10.1109/tcyb.2020.3005893.

[95] Y. Lin, G. Nan, Y. Li, H. Luo, W. Fan, Energ. Fuel., 2017, 31, 11911-11917, doi: 10.1021/acs.energyfuels.7b02227.

[96] A.S.V. da Silva, R. Weinschutz, C.I. Yamamoto, L.F.L. Luz, Jr., Fuel, 2013, 106, 632-638, doi: 10.1016/j.fuel.2012.12.024.

\section{Author information}

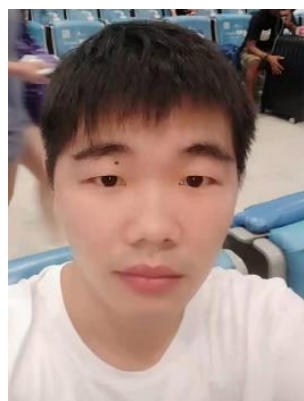

Duo Pan, currently a Ph.D. candidate in National Engineering Research Center for Advanced Polymer Processing Technology at Zhengzhou University, China, obtained a degree of Master of Science in Shandong University of Science and Technology (2019). His research interest focuses on the preparation of functional polymer materials and nanocomposites, as well as applications in catalytic degradation and heat conduction.

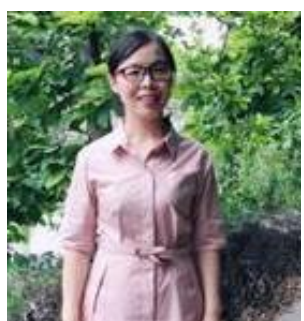

Fengmei $\mathbf{S u}$ is an associate professor a the National Engineering Research Center for Advanced Polymer Processing Technology of Zhengzhou University. She obtained her Master's and Ph.D. degree from University of Science and Technology of China with Prof. Liangbin Li (2011-2016). His current research interest focuses on polymer crystallization and phase transition, aerospace neutron radiation protection composite materials, and thermal conduction and electromagnetic shielding functional composite materials.

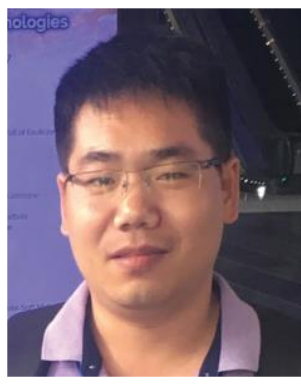

Hu Liu is an associate professor at the National Engineering Research Center for Advanced Polymer Processing Technology of Zhengzhou University. He obtained his PhD from Zhengzhou University (2017), and then worked as a joint PhD student with Prof. Zhanhu Guo at the University of Tennessee, Knoxville, USA, sponsored by the China
Scholarship Council (2015-2016). His current research interest focuses on multifunctional polymerbased nanocomposites, especially conductive polymer composite-based sensors, electromagnetic shielding materials, and thermal insulating aerogel.

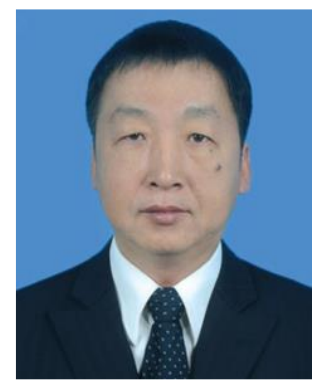

Chuntai Liu is currently a professor at the National Engineering Research Center for Advanced Polymer Processing Technology (NERC) of Zhengzhou University. He obtained his PhD from Zhengzhou University (2003), and then worked as a visiting scholar at Ohio State University, USA (20062007). He serves as the deputy director of NERC of Zhengzhou University. His research focuses on multifunctional polymer composites, including their processing and microstructure properties.

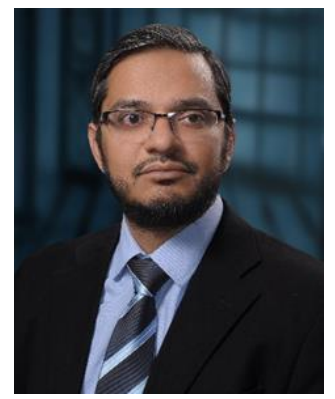

Ahmad Umar Professor Ahmad Umar received his $B . S c$. in biosciences and M.Sc. in inorganic chemistry from Aligarh Muslim University (AMU), Aligarh, India, and Ph.D. in semiconductor and chemical engineering from Chonbuk National University, South Korea. He worked as a research scientist in Brain Korea 21, Centre for Future Energy Materials and Devices, Chonbuk National University, South Korea, in 2007-2008. Afterwards, he joined the Department of Chemistry in Najran University, Najran, Saudi Arabia. He is a distinguished professor of chemistry and is the current deputy director of the Promising Centre for Sensors and Electronic Devices (PCSED), Najran University, Najran, Saudi Arabia. Professor Ahmad Umar is specialized in 'semiconductor nanotechnology', which includes growth, properties and their various high technological applications, for instance, gas, chemicals and biosensors, optoelectronic and electronic devices, field effect transistors (FETs), nanostructure-based energy-harvesting devices, such as solar cells, Liion batteries, super-capacitors, semiconductor nanomaterialbased environmental remediation, and so on. He contributed to the world of science by editing world's first handbook series on Metal Oxide Nanostructures and Their Applications (5-volume set, 3500 printed pages, www.aspbs.com/mona) and handbook series on Encyclopedia of Semiconductor Nanotechnology (7-volume set; www.aspbs.com/esn), both published by ASP. He has authored 30 book chapters, over 600 research/review articles and technical notes in peer-reviewed international journals, and more than 200 proceedings, abstracts and technical reports. He has 6 patents either issued or applied for on metal oxide nanostructures and their based sensors and electronics devices. Based on his research achievements, his citation records are as follows: Citations: over 19000, h-index: 70, i10 index: 354. 


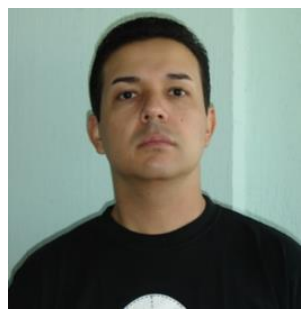

Luis Castañeda graduated from the $\mathrm{Na}$ tional Autonomous University of Mexico (UNAM) in 1998 with Physics Degree. In 2003, he received his Doctorate degree in Materials Science and Engineering from the same University. $L$. Castañeda has worked for several years in the field of preparation of semiconductor metal oxides in thin film form, photoluminescence, optical properties of semiconductors and chemical sensing devices for different gases. On the other hand, L. Castañeda has published around ninety articles in various internationally prestigious arbitration journals and has around eight hundred citations; likewise, he has published four book chapters and four books in prestigious international publishers. L. Castañeda is editor-in-chief of 4 high-impact journals; I have been an arbitrator of more than 500 manuscripts that have been submitted in high-impact journals, he has an $h$ factor of 22. At this moment, $L$. Castañeda is designing and implementing the laboratory for the preparation of samples in the form of a thin film by means of the pneumatic and ultrasonic chemical spray process in the Section of Graduate Studies and Research of the Higher School of Medicine, National Polytechnic Institute, Plan of San Luis and Díaz Mirón S/N, Casco de Santo Tomás, Mexico, Federal District 11340, Mexico.

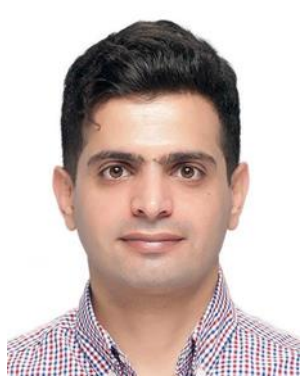

Hassan Algadi has completed his Bachelor and Master degrees from King Saud University and Rochester Institute of Technology in 2004 and 2010, respectively in Electrical Engineering specialization. After successfully completing MS, Dr. Algadi joined Najran University as Lecturer in Electrical Engineering. Dr. Algadi completed his PHD in 2019 from Yonsei University, South Korea in Electrical Engineering. Currently, Dr. Algadi is working as an Assistant Professor at the Department of Electrical Engineering, College of Engineering, Najran University, Saudi Arabia. He is working as a senior researcher at the Center for Advanced Materials and Nano-Research, Najran University. He is specialized in Nanoelectronic devices, sensors and Nano-biology related research. He has published many articles in his specialized research area and received hundreds of citations on his research.

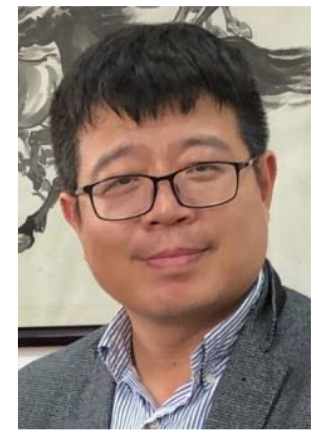

Zhanhu Guo earned his Ph.D. degree in chemical engineering from Louisiana State University in 2005. He received his three-year postdoctoral training in mechanical and aerospace engineering at the University of California Los Angeles. He is a Professor in Chemical and Biomolecular Engineering directs the Integrated Composites Laboratory at The University of Tennessee, Knoxville. His current research interests are in the areas of optoelectronic, electric, and magnetic materials for solar cells, catalysis, sensing, and electronics.

Publisher's Note: Engineered Science Publisher remains neutral with regard to jurisdictional claims in published maps and institutional affiliations. 